\title{
SYNOD NEWS
}

\section{THE GOVERNING BODY OF THE CHURCH IN WALES}

\author{
CHARLES ANDERSON \\ Solicitor to the Province of Wales
}

The Governing Body met in September 2000 and September 2001. The April 2001 meeting was cancelled because the foot and mouth outbreak was widespread in Wales and it was felt wrong to ask members to travel widely through rural areas at such a time. Accordingly this account covers the two September meetings.

\section{September 2000}

1979 marked the twenty-fifth anniversary of the covenant between the Church in Wales and a number of other denominations under which the parties to the covenant undertook to seek a closer relationship with one another. The original parties in addition to the Church in Wales were the Calvinistic Methodist Church of Wales, the Presbyterian Church of Wales, the Methodist Church, the United Reformed Church of England and Wales and members of the Union of Welsh Independents. In 1977 the Province made a covenant in the same terms with such churches belonging to the Baptist Union of Great Britain and Ireland as wished to do so. This grouping is known as "ENIFYS", the Welsh word for "rainbow". To mark the occasion, the Right Reverend Huw Jones, Bishop of St Davids and the Church in Wales Bishop with responsibility for ecumenical affairs and for years closely involved with ENFYS, delivered an erudite and fascinating lecture tracing the development of the workings of the covenant over the period since its inception.

In business terms the Governing Body was informed of a number of proposed amendments to the Constitution, covering such matters as the question of the eligibility of retired clergy to be members of Diocesan Conferences, the proposed changes to provisions relating to the retiring age of Diocesan Registrars, Chancellors and the Registrar of the Church in Wales Provincial Court, and also proposals to review the provisions of Chapter $\mathrm{V}$ of the Constitution which relate to Ruridecanal Conferences. In addition it was agreed that clerics who have completed forty years pensionable service before reaching the age of 65 should be entitled to retire on full pension at that point without any actuarial reduction of pension to reflect the early retirement.

Apart from these matters, the most significant issue on the agenda at this meeting was the Bill to establish a Disciplinary Tribunal and make the necessary consequential amendments to Chapter XI of the Constitution. The changes involved the establishment of the new Tribunal and provision for it to work in two stages. Initially all references (which have to come from a Diocesan Bishop in the first instance) are considered by an Investigatory Committee of five members whose responsibility it is to consider whether the issue can be resolved, if appropriate, through reconciliation. If this proves impossible, the case will be heard by a panel of five different members on a formal basis who have power to dispose of the issue subject to an appeal to the Provincial Court. Members of the Tribunal are chosen from a wide variety of backgrounds to reflect the need for representation across the Province and a wide degree of specialist expertise, including legally qualified members and those with either medical or counselling qualifications. 
The Governing Body in committee considered the detailed report of its Select Committee which was presented by the Chairman, Mr Gilderoy Glossop, and heard a number of contributions from different members. The Bill was eventually passed, there being no votes against it and only one abstention.

\section{Septemher 2001}

This was a particular busy meeting as it had to deal with business which would have been dealt with in April but for the cancellation of that meeting.

A final decision was taken on the form of the amendments to Chapter IV of the Constitution, mentioned above, dealing with clerical membership of Diocesan Conferences. The Report of the Working Group set up previously to review the workings of Chapter V of the Constitution in respect of Ruridecanal Conferences was presented by its Chairman, the Archdeacon of Meirionnydd, the Venerable Carl Cooper, and accepted by the Governing Body. In addition to this, approval was given to certain amendments to the Llandaff Cathedral Scheme, which deals with the Constitution and working of the Dean and Chapter, to provide for the fact that the Diocese has decided to create an additional Archdeaconry and allow for the third Archdeacon to be a member of the Chapter.

These matters were dealt with in the context of the Standing Committee's report covering the entire period since the last meeting in September 2000 and immediately afterwards the Governing Body heard, and with some amendments accepted, an emergency motion arising from the attack on the World Trade Centre in New York on 11 September. This had struck particularly close because the Archbishop had been in Manhattan at the time of the attack, preparing to deliver an address, and had been in serious danger for several hours. Thankfully he was safely preserved and in his Presidential Address spoke with characteristic clarity about the issues which these horrific events raised. It should be noted in this context that Dr Williams has consistently declined to give personal interviews about his experiences on the grounds that he personally was not the story, and in line with this view, his address concentrated on the wider implications of the events.

The Governing Body dealt with a wide range of business matters, including the passing of a Bill to allow for the early retirement of clergy who had accumulated forty years service prior to reaching the age of 65 and also of the Bill dealing with the retirement age of various provincial officers (both of which are referred to in the context of the report for last September - see above).

The September meeting is the occasion when the Governing Body receives the report of the Representative Body and on this occasion, as well as a number of more routine issues. a proposal was presented to re-order the provisions dealing with clergy pensions. Currently these appear as Part II of Chapter XII of the Constitution but it was proposed that a re-ordered version, taking account of various changes since the present text was agreed, should be transferred to become part of the Maintenance of Ministry Scheme so that all provisions relating to the financial support of clergy should be kept in the same place. The proposals had been discussed at an open meeting held the night before they were presented to the full session and they were agreed by the Governing Body.

The other main issue considered at this meeting was a report presented by the Standing Committee on the size and frequency of meetings of the Governing Body. This covered a wide range of issues and sought to take account of the fact of changes 
in numbers over the years plus the fact that whilst the agenda at some meetings is very heavy, at others it is particularly light, and it explored ways of evening out the peaks and the troughs. The report was the product of many hours of work by the members charged with the responsibility of preparing it and of much discussion by the Standing Committee itself. It provoked a lively debate and a wide variety of opinion. Eventually it became clear that the Governing Body wished to see a number of the proposals shaped differently and it agreed to the proposal that further discussion should be postponed until revisions to the report, taking account of the views expressed, had been prepared ready for further discussion.

\title{
THE GENERAL SYNOD OF THE CHURCH OF ENGLAND
}

\author{
STEPHEN SLACK \\ Registrar and Legal Adviser to the General Synod
}

This Report covers two Groups of Sessions: those held in July and November 2001.

At the July Group of Sessions, the Synod gave final approval to the Synodical Government (Amendment) Measure (bishops, $24: 0$; clergy, $160: 4$; laity, 175: 14). The Measure gives effect to a number of recommendations made by the Bridge Report on Synodical Government in the Church of England which were seen as uncontroversial (see 5 Ecc LJ 383). Other proposals derived from the Bridge Report, largely concerned with the size and composition of the General Synod itself and therefore of a more contentious nature, were also discussed at the July Group of Sessions. Following a debate widely seen as unsatisfactory, they were subject to a number of changes. The Business Committee must now consider in just what form the proposals should be brought back to Synod.

Unusually, the two Groups of Sessions also saw the completion between them of all the stages of a new piece of legislation, the Church of England (Pensions) Measure. First consideration having been given in July, the absence of any proposals for amendment meant that it was possible to complete the remaining stages in November (final approval: bishops, $28: 1$; clergy, $164: 0 ;$ laity, $174: 0$ ). The Measure makes changes in two main areas connected with pensions: it amends the powers of the Church of England Pensions Board in several technical respects (including by amalgamating a number of discretionary funds in the interests of effectiveness); and it extends beyond its expiry date of 31 December 2004 the power which the Pensions Measure 1997 conferred upon the Church Commissioners to spend capital in satisfaction of their pre-1998 pensions liabilities.

The Synodical Government (Amendment) Measure and the Church of England (Pensions) Measure now join the Clergy Discipline Measure (see 5 Ecc LJ 382 and 6 Ecc LJ 89) in being committed to the Legislative Committee for submission to the Ecclesiastical Committee of Parliament. Although it received final approval in July 2000 , the Clergy Discipline Measure has not progressed further because of the need to reconstitute the Ecclesiastical Committee following the General Election. At the date of writing, details of the Committee's membership are still awaited. 